\section{Structural Relationships Among Variables Affecting Elementary School Students' Career Preparation Behavior: Using a Multi- Group Structural Equation Approach}

Sun Hee Park ${ }^{a}$, JuSung Jun ${ }^{b^{*}}$

\begin{tabular}{ll}
\hline Received: & 23 October 2017 \\
Revised: & 1 December 2017 \\
Accepted: & 5 December 2017 \\
ISSN: 1307-9298 \\
Copyright @ IEJEE \\
www.iejee.com
\end{tabular}

DOI: $10.26822 /$ iejee.2017236122

\begin{abstract}
The purpose of this study was to analyze the structural relationships between parent support, career decision self-efficacy, career maturity, and career preparation behavior for elementary school students (5th and 6th grade) in Korea and to examine if there are gender differences. A total of 609 students of 7 elementary schools in Seoul, Korea was participated in this research. The collected data were analyzed using a structural equation model. The conclusions are as follows: First, parent support had significant positive effects on career preparation behavior but affected negatively career maturity. Second, career decision self-efficacy had a significant effect on career maturity and career preparation behavior for both boys and girls in elementary school. Finally, career decision self-efficacy had a more direct and indirect influence on career maturity and career preparation behavior than parent support.
\end{abstract}

Keywords: Career preparation behavior, parent support, career decision self-efficacy, career maturity.

\section{Introduction}

As the Fourth Industrial Revolution unfolds, transforming and disrupting many existing models and processes, the job market has come to be characterized by instability and unpredictability. Resultantly career education, especially for adolescents, is now a subject of great importance. Some developed countries are developing and operating career development programs from the elementary school level in order to prepare for such a future society (Coogan, 2016). Recognizing this, the Korean government enacted the Career Education Act (June 22, 2015) and the Enforcement Decree of the Career Education Act (December 22, 2015) to establish the basic direction and a support system for career education, which included putting in place national career education goals and achievement standards. The government has also placed specialist career teachers in secondary schools and introduced a system for career education in primary and secondary schools.

The 2015 amendment specifies the goals of elementary school career education as being creating a positive selfconcept, recognizing the importance of employment, and fostering basic career development skills through developing key skill-sets such as job searching, planning and preparation (Ministry of Education, 2015). Career education in elementary schools focuses on the career recognition stage. In particular, the 5th and 6th grades of elementary school are seen as a vital time for students to consider and even select their own careers, and a time when it is necessary to provide opportunities for systematic career searching (Lee, Lee, \& Lee, 2016). In recent years, several studies (Ahn, 2008; Chung, 2014;
Gushue \& Whitson, 2006; Han \& Cho, 2016; Han \& Oh, 2014; Seo, 2016) have been conducted on the variables that affect career preparation behavior and how they fit into career education for adolescents. In particular, variables that have been studied extensively in career preparation behavior research include parent support, career decision self-efficacy, and career maturity. Career preparation behavior is usually understood as the concrete and practical behavioral efforts undertaken in the process of achieving career goals. Career preparation behavior should be undertaken as part of the process of finding a reasonable and suitable career, and it includes all actions to implement a decision about a career after that decision is reached (Kim, 1997). Parent support is an environmental variable that represents the perception of children about the way that their parents provide educational and occupational efficacy information (Ahn, 2008). Parent support is information that allows children to believe that their parents are caring and loving, that they are proud of their children, and that they are members of an accountable communication network (Cobb, 1976). Following Ahn (2008), in this study, the researchers define career-related parent support as the perception of children about how their parents provide educational and occupational efficacy information. Hackett and Betz (1981) applied Bandura's concept of self-efficacy to career development theory as an important cognitive variable affecting career decision process. They conceptualized 'career self-efficacy' specifically for the individual's efficacy related to career choice and adaptation. Career decision self-efficacy can be defined as beliefs about the individual's ability to successfully perform tasks related to career decisions

\footnotetext{
a Seoul Semyung Elementary School, E-mail: chrysta@sen.go.kr

b,* Corresponding author: JuSung Jun, Soongsil University, Department of Lifelong Education, 369 Sangdo-Ro, Dongjak-Gu, Seoul, 06978, Korea. E-mail: jnet@ssu.ac.kr
} 
according to the definition of Hackett and Betz (1981). Career maturity is defined as the degree to which an individual understands and evaluates himself/herself and selects and adapts his/her career path (Chung, 2014).

Previous studies demonstrate positive relationships between the variables of parent support, career decision self-efficacy, career maturity, and career preparation behavior. Firstly, Gushue and Whitson (2006) and Pečiulytè, Ustinavičiūtè, and Norvilè (2014) found that there was a positive relationship between high school student's parent support and career decision self-efficacy (Pečiulytè, Ustinavičiūtè, \& Norvilè, 2014). Secondly, Han and Oh (2014) indicated that parent support had a significant effect on the levels of career maturity of high school students. Choi (2016) also found that middle school students who perceived parent support levels as high were highly confident about their careers, and were able to independently undertake career preparation and determine their career paths. In other words, parent support had a positive impact on students' career maturity. Thirdly, Ahn (2008) and Han and Cho (2016) showed that parent support has a positive effect on career preparation behavior. Fourthly, Lee and Cho (2015) and Seo (2016) showed that college students' career maturity had a significant effect on their career preparation behavior. Fifthly, Walker (2010), Lee and Lee (2000) found that career decision self-efficacy of college students had a positive effect on career maturity. Finally, Kim and Lee (2013) reported that the higher the levels of career decision self-efficacy of middle and high school students, the more career preparation behavior they engaged in. Seo (2016) also indicated that career decision self-efficacy had a positive effect on the career preparation behavior of college students.

However, the above studies all focused only on high school and college students, and also sought to identify only simple relationships between two of the variables in question. In other words, existing studies have had a major interest in identifying variables that affect career preparation behavior of high school and college students. This study attempts to analyze the multiple and causal relationships among the main variables that affect career preparation behavior through a single structural equation model. In the context of the importance of career education for elementary students, it is necessary to analyze the structural influences of the variables.

The purpose of this study is to analyze the structural relationships between the variables of parent support, career decision self-efficacy, career maturity, and career preparation behavior for elementary school students (5th and 6th grade), and further to examine if there are gender differences in these relationships. The results of this study can contribute not only to theorizing the multifaceted relationships among the variables that influence the level of career preparation behavior of elementary students, but also to suggesting the implications for elementary students' career research.

\section{Methodology}

\section{Research Model}

In this study, the researchers derived a research model(see Figure 1) based on the results of previous studies on parent support, career decision self-efficacy, career maturity, and career preparation behavior.

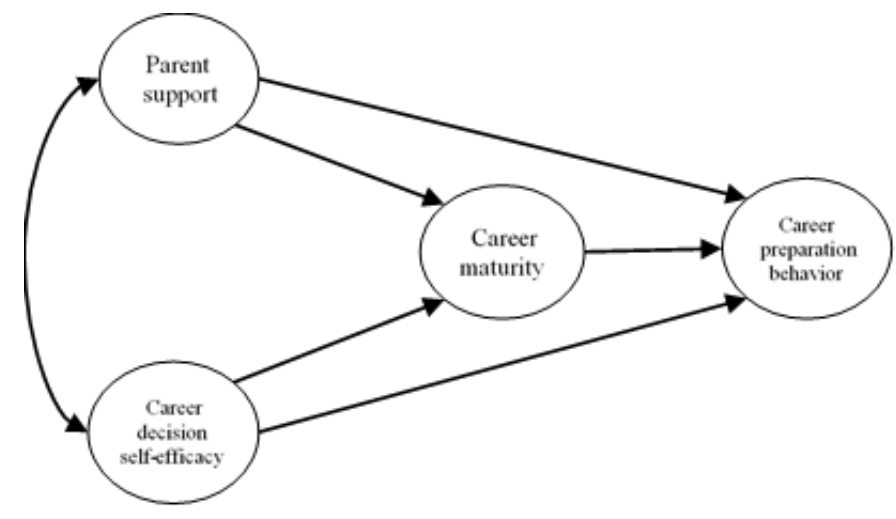

Figure 1. Research model

Research based on this type of design aids researchers and educators to better understand how to orchestrate learning experiences among children in a daily educational context, and at the same time, how to develop theoretical ideas regarding the nature of learning (Bell, 2004). Consequently, the research design takes into consideration primarily understanding of the processes and the strategies that help learners to be successful in solving math word problems.

\section{Research Samples and Data Collection}

This study was conducted on 5th and 6th grade students at seven elementary schools in Seoul, Korea. A total of
638 questionnaires were collected and 609 were used (responses deemed untruthful were excluded). Listwise deletion was used for handling missing data. Of the respondents, 304 (49.9\%) were boys and 305 (50.1\%) were girls. There were 324 students $(53.2 \%)$ in the 6 th grade and 285 students $(46.8 \%)$ in the 5 th grade.

\section{Measurement Scales}

Parent support scale. For the parent support scale the 'Career-related Parent Support Scale' developed by Tuner, Annette, Lapan, Udipi, and Ergun (2003) and translated into Korean by Kim (2004) was used. The scale consists of the four sub-factors of career-related modeling, 
emotional support, instrumental support, and verbal support. It has a total of 27 items and uses a 5-pointLikert scale format. In the present study, the whole Cronbach a for the parent support scale was .94, and Cronbach a for the sub-factors was career-related modeling .89, emotional support .88, instrumental support .85 , and verbal support .81

Career decision self-efficacy scale. For this scale the 'Career Decision-Making Self-Efficacy Scale, CDMSES' developed by Taylor and Betz (1983) and validated by Lee (2001) for middle and high school students was used. This scale consists of the four sub-factors of goal selection, job information, problem solving, and future planning. It has a total of 25 items and uses a 5-point Likert scale format. In this study, the overall Cronbach a for the career decision self-efficacy scale was .95, and Cronbach a for the sub-factors was goal selection .92, job information .85, problem solving .73, and future planning .83 .

Career maturity. In this study, the researchers used the career maturity measurement tool developed by the National Youth Policy Institute (2010). It has a total of 7 items and uses a 5-point-Likert scale format. The Cronbach a of the seven items was .72.
Career preparation behavior scale. The career preparation behavior scale was developed by Choi, Kim, Hwang, and Huh (2009) in order to measure the career preparation behavior of youth. This scale consists of the two sub-factors of career exploration and career development, and includes 10 items. A Likert type 5 point scale was used. In this study, the overall Cronbach a for the career preparation behavior scale was .84, and Cronbach a for the sub-factors was career exploration .74 and career development .76 respectively.

\section{Data Analysis}

In order to investigate the normal distribution of observational variables, descriptive statistics such as mean, standard deviation, skewness, and kurtosis of the variables were analyzed using SPSS. In addition, the fitness of the research model was estimated by applying the maximum likelihood method (ML) using AMOS.

\section{Results}

\section{Descriptive Statistics and Correlations}

Table 1 revealed that the descriptive statistics of the measurement variables are not problematic for the normality assumption. Table 2 represents the correlation matric between variables.

Table 1. Descriptive Statistics $(N=609)$

\begin{tabular}{|c|c|c|c|c|c|c|c|c|c|}
\hline \multirow{2}{*}{$\begin{array}{c}\text { Latent } \\
\text { variables }\end{array}$} & \multirow{2}{*}{$\begin{array}{l}\text { Observed } \\
\text { variables }\end{array}$} & \multicolumn{2}{|c|}{ Total(609) } & \multicolumn{2}{|c|}{ Boys(304) } & \multicolumn{2}{|c|}{ Girls(305) } & \multirow{2}{*}{ Skewness } & \multirow{2}{*}{ Kurtosis } \\
\hline & & $\mathrm{M}$ & SD & $\mathrm{M}$ & SD & $\mathrm{M}$ & SD & & \\
\hline \multirow{4}{*}{$\begin{array}{c}\text { Career } \\
\text { decision self- } \\
\text { efficacy }\end{array}$} & Goal selection & 3.780 & .772 & 3.774 & .809 & 3.786 & .734 & -.502 & .253 \\
\hline & $\begin{array}{c}\text { Job } \\
\text { information }\end{array}$ & 3.492 & .838 & 3.522 & .880 & 3.462 & .795 & -.158 & -.135 \\
\hline & $\begin{array}{c}\text { Problem } \\
\text { solving }\end{array}$ & 3.463 & .861 & 3.467 & .932 & 3.459 & .785 & -.074 & -.274 \\
\hline & $\begin{array}{c}\text { Future } \\
\text { planning }\end{array}$ & 3.441 & .852 & 3.497 & .895 & 3.385 & .806 & -.114 & -.148 \\
\hline \multirow{4}{*}{$\begin{array}{l}\text { Parent } \\
\text { support }\end{array}$} & Modeling & 3.754 & .985 & 3.751 & 1.013 & 3.756 & .958 & -.620 & -.293 \\
\hline & $\begin{array}{l}\text { Emotional } \\
\text { support }\end{array}$ & 3.451 & .924 & 3.424 & .945 & 3.477 & .903 & -.417 & -.155 \\
\hline & $\begin{array}{l}\text { Instrumental } \\
\text { support }\end{array}$ & 3.140 & .887 & 3.156 & .897 & 3.123 & .877 & -.242 & -.322 \\
\hline & Verbal support & 3.671 & .909 & 3.722 & .914 & 3.620 & .903 & -.540 & -.136 \\
\hline \multirow{2}{*}{$\begin{array}{l}\text { Career } \\
\text { preparation } \\
\text { behavior }\end{array}$} & $\begin{array}{c}\text { Career } \\
\text { exploration }\end{array}$ & 3.057 & .875 & 3.015 & .911 & 3.098 & .838 & .030 & -.434 \\
\hline & $\begin{array}{c}\text { Career } \\
\text { development }\end{array}$ & 3.619 & .940 & 3.566 & .984 & 3.672 & .893 & -.494 & -.269 \\
\hline $\begin{array}{l}\text { Career } \\
\text { maturity }\end{array}$ & $\begin{array}{c}\text { Career } \\
\text { maturity }\end{array}$ & 3.812 & .710 & 3.803 & .715 & 3.822 & .707 & -.253 & -.322 \\
\hline
\end{tabular}

Table 2. Correlations between Variables

\begin{tabular}{|c|c|c|c|c|c|c|c|c|c|c|c|}
\hline & \multicolumn{4}{|c|}{ Career decision self-efficacy } & \multicolumn{4}{|c|}{ Parent support } & \multicolumn{2}{|c|}{$\begin{array}{c}\text { Career preparation } \\
\text { behavior }\end{array}$} & \multirow{2}{*}{$\begin{array}{c}\begin{array}{c}\text { Career } \\
\text { maturity }\end{array} \\
11\end{array}$} \\
\hline & 1 & 2 & 3 & 4 & 5 & 6 & 7 & 8 & 9 & 10 & \\
\hline 1 & 1 & & & & & & & & & & \\
\hline 2 & $.792 \star \star$ & 1 & & & & & & & & & \\
\hline 3 & $.460 * \star$ & $.500 \star \star$ & 1 & & & & & & & & \\
\hline 4 & $.838^{* *}$ & $.802^{\star \star}$ & $.483^{* \star}$ & 1 & & & & & & & \\
\hline 5 & $.406^{\star \star}$ & $.433 * \star$ & $.314^{\star \star}$ & $.390 * \star$ & 1 & & & & & & \\
\hline
\end{tabular}


Table 2 (Cont.). Correlations between Variables

\begin{tabular}{|c|c|c|c|c|c|c|c|c|c|c|c|}
\hline 6 & $.543^{\star \star}$ & $.540 * *$ & $.319 * *$ & $.549 * \star$ & $.471 * \star$ & 1 & & & & & \\
\hline 7 & $.518^{* \star}$ & .532 ** & $.326^{* *}$ & $.556 * \star$ & $.498^{* *}$ & $.750 * \star$ & 1 & & & & \\
\hline 8 & $.497 \star \star$ & $.486 * *$ & $.363^{* *}$ & $.485^{\star \star}$ & .430 ** & $.724 \star \star$ & $.633^{* \star}$ & 1 & & & \\
\hline 9 & $.584^{\star \star}$ & $.575 * \star$ & $.307 * \star$ & $.536 * \star$ & .401 ** & $.445^{\star \star}$ & $.470 * \star$ & $.326 * \star$ & 1 & & \\
\hline 10 & $.659 * \star$ & .581 ** & .291 ** & $.608^{* \star}$ & $.340^{\star \star}$ & $.459 * \star$ & $.497 \star \star$ & $.357 * \star$ & $.655^{\star \star *}$ & 1 & \\
\hline 11 & $.508 * \star$ & $.404^{* *}$ & $.083 *$ & $.475^{\star *}$ & $.199 * \star$ & $.215^{\star \star}$ & $.286 \star \star$ & $.119 * *$ & $.341 * \star$ & $.409 * *$ & 1 \\
\hline
\end{tabular}

\section{Structural Relationships of the Research Model}

Verification of model fit. The model fit of the initial model is $x^{2}=196.804 \quad(d f=39, \quad p<.001), \quad$ TLI (Tucker-Lewis Index)=.947, CFI (Comparative Fit Index) $=.962$, and RMSEA(Root Mean Square Error of Approximation) $=.082$. The values of TLI and CFI are over .90, which indicates that the initial structural model meets the criteria for fitness. Therefore, the initial model was selected as the final model without modification.

The results of the standardized model estimation of the final structural regression model are shown in Figure 2, and the statistical significance test results are shown in Table 3. Additionally, the indirect, direct, and total effects of path coefficients between the variables are shown in Table 4.

Looking at the path coefficients between variables, parent support ( $\beta=-.19)$ had a negative impact on career maturity, and career decision self-efficacy $(\beta=.64)$ had a significant positive effect on career maturity. In addition, parent support $(\beta=.17)$ and career decision self-efficacy $(\beta=.64)$ had a significant effect on career preparation behavior. The total effect of parent support and career decision self-efficacy on career preparation behavior was $.152, .701$, respectively. Career decision self-efficacy was found to be more influential on career preparation behavior than parent support.

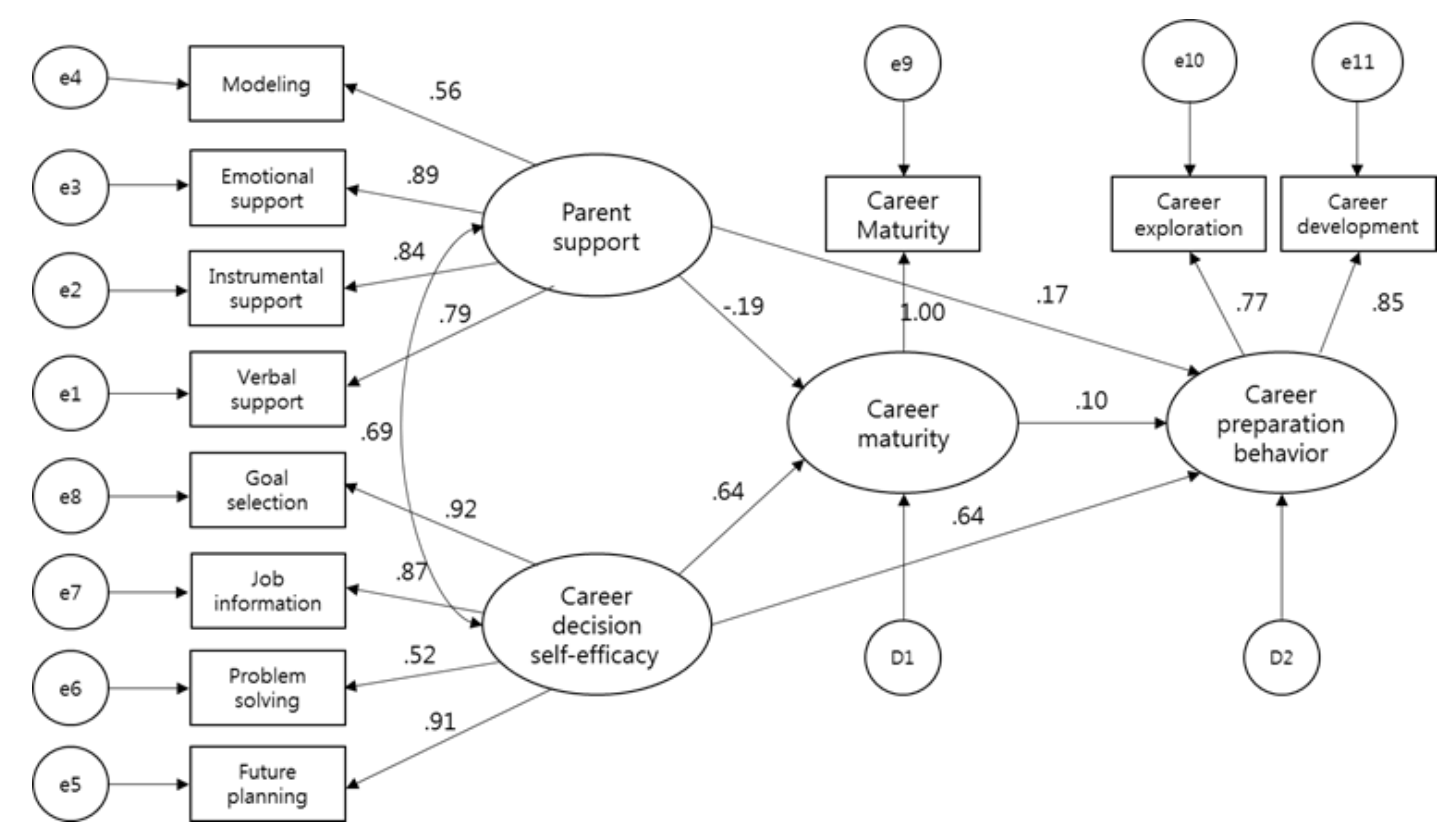

Figure 2. The structural regression model (standardized coefficient)

Table 3. Parameter Estimation and Significance Verification of the Structural Regression Model

\begin{tabular}{lcccc}
\multicolumn{1}{c}{ Path } & $\begin{array}{c}\text { Unstandardized } \\
\text { estimate }\end{array}$ & $\begin{array}{c}\text { Standardized } \\
\text { estimate }\end{array}$ & S.E. & C.R \\
\hline Parent support $\rightarrow$ Career maturity & -.186 & -.188 & .056 & $-3.331^{\star \star \star}$ \\
Career decision self-efficacy $\rightarrow$ Career maturity & .585 & .641 & .051 & $11.436^{\star \star \star}$ \\
Career maturity $\rightarrow$ Career preparation behavior & .094 & .098 & .037 & $2.562^{\star *}$ \\
Career decision self-efficacy $\rightarrow$ Career preparation behavior & .555 & .638 & .054 & $10.315^{\star \star *}$ \\
Parent support $\rightarrow$ Career preparation behavior & .161 & .171 & .049 & $3.283^{* *}$ \\
\hline
\end{tabular}


Table 4. Direct Effect, Indirect Effect, Total Effect of Path Coefficients between Latent Variables

\begin{tabular}{lccc}
\hline \multicolumn{1}{c}{ Path } & Direct effect & Indirect effect & Total effect \\
\hline Parent support $\rightarrow$ Career maturity & -.188 & - & -.188 \\
Career decision self-efficacy $\rightarrow$ Career maturity & .641 & - & .641 \\
Career maturity $\rightarrow$ Career preparation behavior & .098 & - & .098 \\
Parent support $\rightarrow$ Career preparation behavior & .171 & -.018 & .152 \\
Career decision self-efficacy $\rightarrow$ Career preparation behavior & .638 & .063 & .701 \\
\hline
\end{tabular}

Table 5. Fit Indices for Measurement Invariance Test

\begin{tabular}{|c|c|c|c|c|c|c|c|}
\hline Model & $\chi^{2}$ & $\mathrm{df}$ & $\mathrm{CFI}$ & TLI & RMSEA & $\Delta \chi^{2}$ & Sig.Dif \\
\hline $\begin{array}{c}\text { [Model 1] } \\
\text { Unconstrained }\end{array}$ & 214.25 & 78 & .774 & .682 & .054 & & \\
\hline $\begin{array}{c}{[\text { Model } 2]} \\
\lambda \text { constrained }\end{array}$ & 216.31 & 85 & .782 & .718 & .050 & 2.06 & No \\
\hline $\begin{array}{c}\text { [Model 3] } \\
\Phi \text { constrained }\end{array}$ & 264.91 & 88 & .958 & .948 & .058 & 50.66 & Yes \\
\hline $\begin{array}{c}{[\text { Model 4] }} \\
\lambda, \Phi \text { constrained }\end{array}$ & 231.05 & 93 & .771 & .729 & .049 & 16.8 & No \\
\hline $\begin{array}{c}{[\text { Model } 5]} \\
\lambda, \Phi, \theta \text { constrained }\end{array}$ & 238.09 & 105 & .779 & .769 & .046 & 23.84 & No \\
\hline
\end{tabular}

\section{Multiple group structural regression models for gender}

Measurement invariance verification. In order to conduct the multiple group path analysis for boys and girls, measurement invariance should be assured that the factor loadings of these groups are the same. The result of the analysis shows that there were no problems with measurement invariance (See Table 5).

\section{Multiple group path analysis for gender}

Figure 3 indicates the results of a multiple group path analysis for gender. Table 6 represents path coefficients comparison for gender between the variables. The indirect effect, the direct effect, and the total effect of the path coefficients for gender between the variables are shown in Table 7. Both boy and girl students had higher career decision self-efficacy influence on career preparation behavior than parent support had on career preparation behavior. The effect of parent support on career maturity was negatively greater for girls $(\beta=-.207)$ than for boys $(\beta=-.183)$. The effect of career decision selfefficacy on career maturity was higher in girls $(\beta=.726)$ than boys $(\beta=.577)$. The effect of parent support on career preparation behavior was higher for girls $(\beta=.20)$ than for boys $(\beta=.14)$. In addition, the effect of career decision selfefficacy on career preparation behavior was higher in boys $(\beta=.689)$ than girls $(\beta=.578)$.

Boys

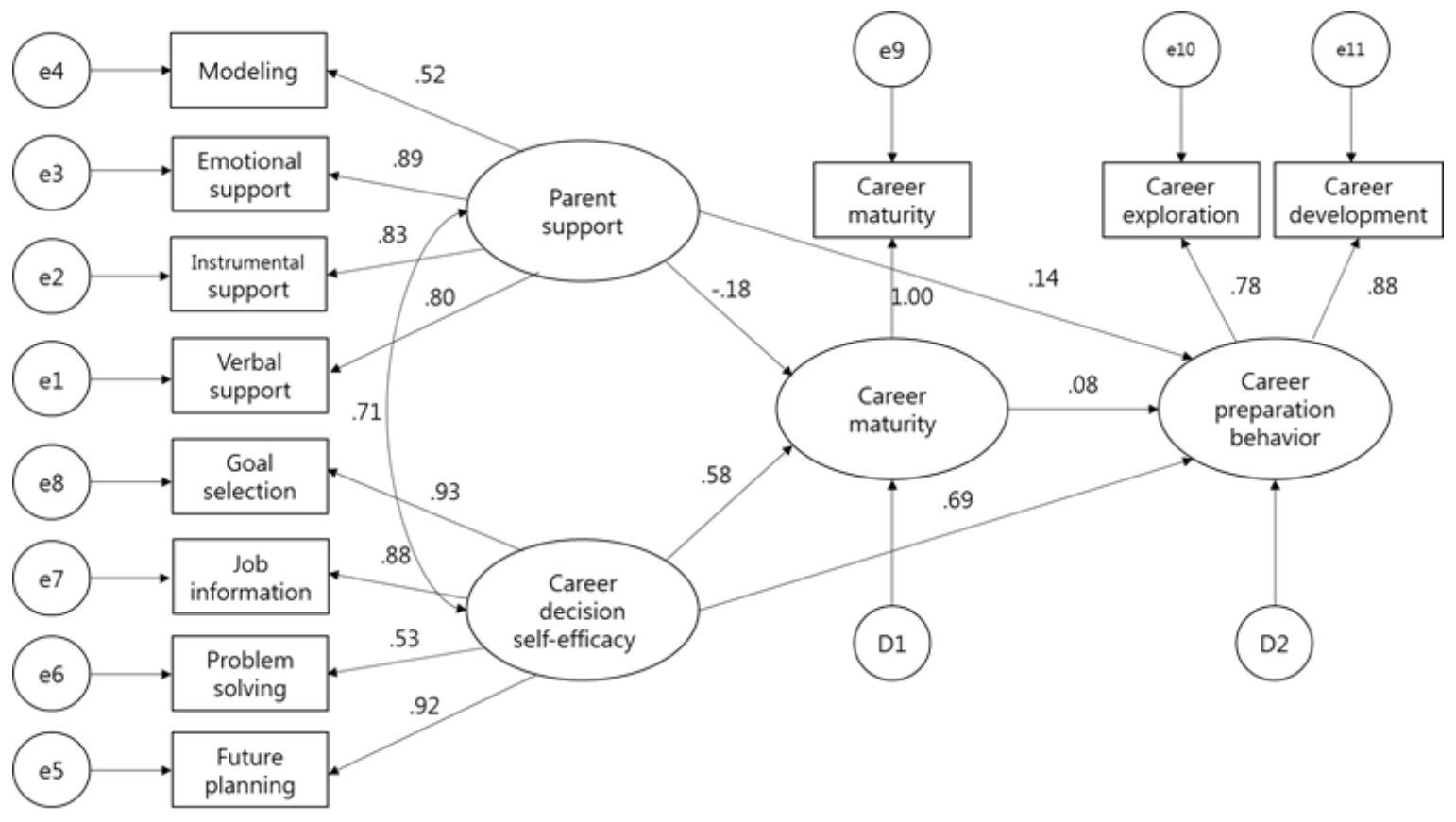


Girls

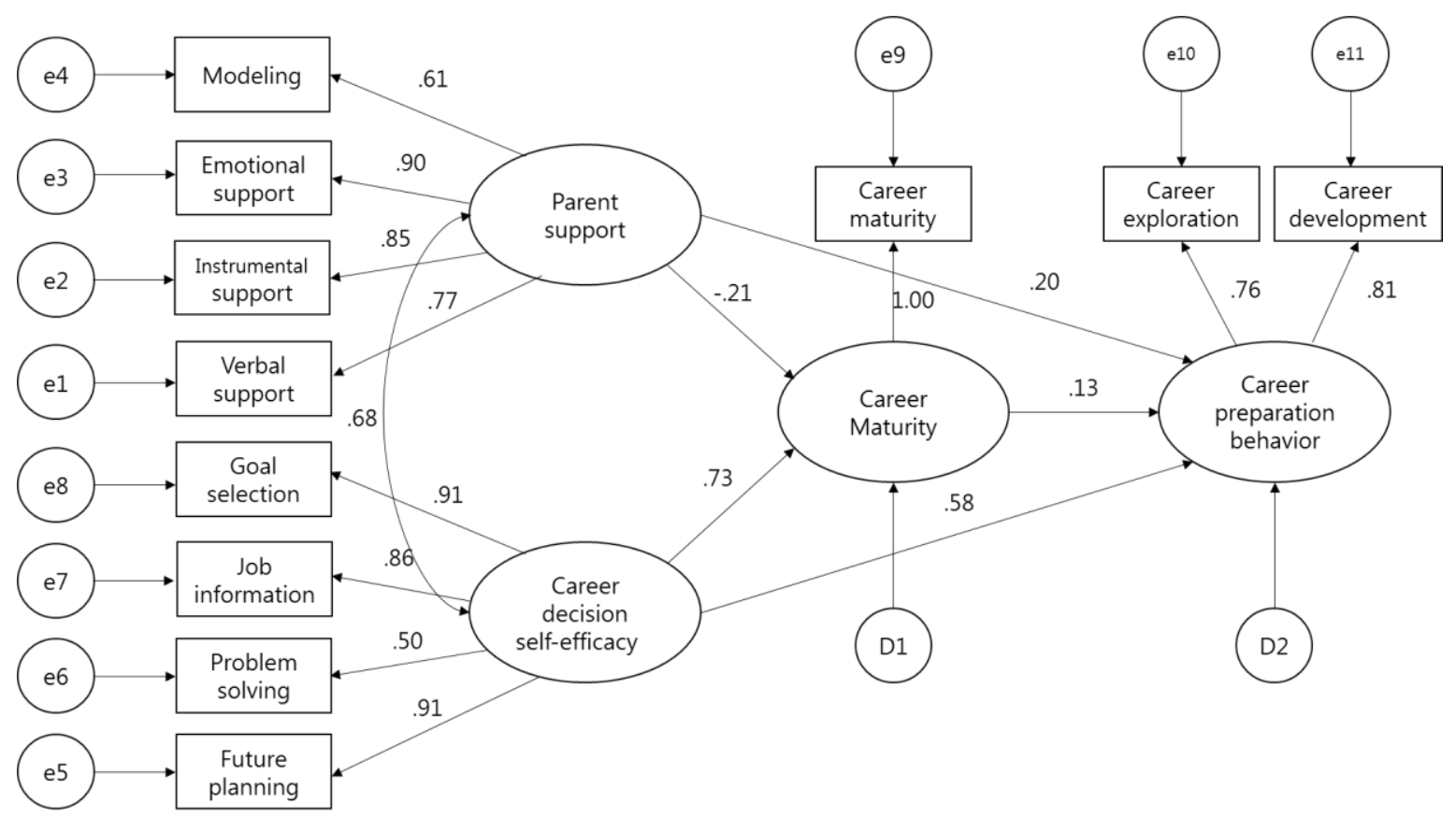

Figure 3. Multiple group structural regression models for gender

Table 6. Path Coefficients Comparison for Gender

\begin{tabular}{|c|c|c|c|c|}
\hline \multirow{2}{*}{ Path } & \multicolumn{2}{|c|}{ Boys } & \multicolumn{2}{|c|}{ Girls } \\
\hline & $\begin{array}{l}\text { Standardized } \\
\text { estimates }\end{array}$ & C.R. & $\begin{array}{l}\text { Standardized } \\
\text { estimates }\end{array}$ & C.R. \\
\hline Parent support $\rightarrow$ Career maturity & -.183 & $-2.191 *$ & -.207 & $-2.766^{\star \star}$ \\
\hline Career decision self-efficacy $\rightarrow$ Career maturity & .577 & $6.988^{* * *}$ & .726 & $9.657^{* * *}$ \\
\hline Career maturity $\rightarrow$ Career preparation behavior & .076 & 1.542 & .132 & $2.136^{*}$ \\
\hline Career decision self-efficacy $\rightarrow$ Career preparation behavior & .689 & $8.328^{* * *}$ & .578 & $6.010 * * *$ \\
\hline Parent support $\rightarrow$ Career preparation behavior & .142 & $2.025^{*}$ & .201 & $2.605^{* \star}$ \\
\hline
\end{tabular}

Table 7. Indirect, Direct, and Total Effects of the Path Coefficients for Gender between Variables

\begin{tabular}{lcccccc}
\multicolumn{1}{c}{ Path } & \multicolumn{2}{c}{ Direct effect } & \multicolumn{2}{c}{ Indirect effect } & \multicolumn{2}{c}{ Total effect } \\
\cline { 2 - 8 } & Boys & Girls & Boys & Girls & Boys & Girls \\
\hline Parent support $\rightarrow$ Career maturity & -183 & -.207 & - & - & -.183 & -.207 \\
Career decision self-efficacy $\rightarrow$ Career maturity & .577 & .726 & - & - & .577 & .726 \\
Career maturity $\rightarrow$ Career preparation behavior & .076 & .132 & - & - & .076 & .132 \\
Parent support $\rightarrow$ Career preparation behavior & .142 & .201 & -.014 & -.027 & .129 & .173 \\
Career decision self-efficacy $\rightarrow$ Career preparation behavior & .689 & .578 & .044 & .096 & .733 & .674 \\
\hline
\end{tabular}

The moderating effect of gender is in $<$ Table $8>$. The effect of career decision self-efficacy on career maturity was only significant: The path coefficient was higher in girls $(\beta=.726)$ than boys $(\beta=.577)$.

Table 8. The Comparison for $\Delta \chi^{2}$ on the Path Coefficients

\begin{tabular}{lccccc}
\hline \multicolumn{1}{c}{ Path } & $\chi^{2}$ & $\mathrm{df}$ & $\chi^{2} / \mathrm{df}$ & $\Delta \chi^{2}$ & Sig.Dif \\
\hline \multicolumn{1}{c}{ Unconstrained Model } & 248.996 & 78 & 3.192 & & \\
\hline Parent support $\rightarrow$ Career maturity & 249.067 & 79 & 3.153 & .07 & No \\
Career decision self-efficacy $\rightarrow$ Career maturity & 252.845 & 79 & 3.202 & 3.85 & Yes \\
Career maturity $\rightarrow$ Career preparation behavior & 249.338 & 79 & 3.156 & .34 & No \\
Career decision self-efficacy $\rightarrow$ Career preparation behavior & 249.719 & 79 & 3.161 & .72 & No \\
Parent support $\rightarrow$ Career preparation behavior & 249.189 & 79 & 3.154 & .19 & No \\
\hline
\end{tabular}




\section{Discussion and Conclusion}

The results of this study showed that parent support perceived by elementary school seniors had a negative effect on career maturity and a positive effect on career preparation behavior, respectively. In addition, parent support indirectly had a significant positive impact on career preparation behavior via career maturity. These results are consistent with the findings (Kim, 2004) that parent career support for middle and high school students had a positive correlation with career preparation behavior but did not directly lead to career maturity. On the other hand, these findings differ from those of Han and Oh (2014) and Choi (2016). These studies have shown that parent support positively influenced career maturity in middle and high school students. This study reveals that parent support may help students in the upper grades of elementary school to navigate and develop the career path, but it may interfere with career maturity if parents are involved excessively. This suggests that in order to strengthen the voluntary career preparation behavior of the elementary school students, the parents need to support their children's opinions and actions with appropriate encouragement while forming cooperative relationships with their children.

The career decision self-efficacy of the upper grades of elementary school showed a direct influence on career maturity and career preparation behavior. In addition, career decision self-efficacy indirectly had a significant positive influence on career preparation behavior via career maturity. These results are consistent with the findings (Cho, 2007; Kim, 2005) that the higher the career decision self-efficacy of college students, the higher the level of career preparation behavior. This study implies that career decision self-efficacy improvement programs encouraging elementary school students to set career goals, collect job information, and solve career-related problems themselves can promote their career preparation behavior. In addition, the direct and indirect effects of career decision self-efficacy on career preparation behavior were more significant than the effects of career-related parent support. This suggests that providing students who do not adequately receive career-related parent support with programs that enhance career decision self-efficacy can promote their career preparation behavior.

In comparison between gender groups, both boy and girl students had higher effects of career decision self-efficacy on career preparation behavior rather than the effects of parent support. In the moderating effect of gender, only the path between career decision self-efficacy and career maturity was statistically significant $(p<.05)$. That is, girl students were higher than boy students in terms of the path coefficient. It is difficult to find studies that analyzed the differences between male and female students concerning the relationships between parent support, career decision self-efficacy, career maturity, and career preparation behavior. This study is significant in that it analyzed the difference in gender on the relationship between these variables. This shows that the results of the study may provide a basis for taking different strategies between boys and girls in providing educational implications.

The conclusions of this study are as follows:

First, parent support had significant positive effects on career preparation behavior but affected negatively career maturity. The results indicate that excessive career-related parenting may have a negative effect on the career maturity of the student. Therefore, it is important that parents form a cooperative relationship with their child from the time the child is in elementary school, and encourage and support their child to voluntarily and independently make decisions. In terms of educational policy, it is also necessary to provide education for parents so that they are aware of how to have a positive role in their child's career guidance. Second, career decision self-efficacy had a significant effect on career maturity and career preparation behavior for both boys and girls in elementary school. This implies that the development and application of career decision self-efficacy improvement programs in elementary education can have a positive effect on the career maturity and career preparation behavior of elementary students. In particular, gender difference analysis showed that the effect of career decision self-efficacy on career maturity was higher in girl students than in boys. This means that career decision self-efficacy improvement programs can be more positive for female students. Finally, career decision self-efficacy had a more direct and indirect influence on career maturity and career preparation behavior than parent support. This implies that active educational intervention is possible to improve the career decision self-efficacy of students.

Career education that equips students with the tools to help them prepare for and adjust to the unpredictable society that they will be adults in is now more important than ever. Up to now, research on career preparation behavior, a key variable in career development, has been mainly conducted for high school students and college students. This study is meaningful as it is a comprehensive analysis of the structural relations among the variables related to career preparation behavior for the upper grades of elementary school students. It is expected that systematic career education will be realized by developing and applying various career decision selfefficacy improvement programs to strengthen career preparation behavior from elementary school onwards. Parent education programs improving parent support are also needed and should be developed and implemented so that students' career preparation behavior can be improved from elementary school.

\section{References}

Ahn, H. K. (2008). The influences of hope, parent support and career barrier on high school student's career preparation behavior (Master's thesis, Dongguk University, Seoul, Korea).

Cho, M. S. (2007). The influence of ego-identity, social support, career decision-making self-efficacy on career maturity and career preparation behavior of 
late adolescence. (Doctoral thesis, Sungkyunkwan University, Seoul, Korea).

Choi, I. J., Kim, B. H., Hwang, M. H., \& Huh, E. Y. (2009). Korea youth indicators survey 4 (Youth career occupation index). Korea Youth Policy Institute.

Choi, M. K. (2016). The relationships between negative affect, social support, and career maturity among adolescents. Korean Journal of Child Studies, 373), 5368. doi:10.5723/kjcs. 2016.37.3.53

Chung, M. J. (2014). The effects of the satisfaction in major and career maturity on the employment anxiety and employment preparation behavior of undergraduates majoring in airline service. Journal of Korean Airline Management, 12(1), 81-104.

Cobb, S. (1976). Social support as a moderator of life stress. Psychosom Med, 38, 300-314.

Coogan, T. A. (2016). Supporting school counseling in Belize: Establishing a middle school career development program. International Electronic Journal of Elementary, 8(3), 379-390.

Gushue, G. V., \& Whitson, M. L. (2006). The relationship among support, ethnic identity, career decision selfefficacy, and outcome expectations in African American high school students: Applying social cognitive career theory. Journal of Career Development, 33(2), 112-124. doi:10.1177/ 089484530 6293416

Hackett, G., \& Betz, N, E. (1981). A self-efficacy approach to the career development of women. Journal of vocational behavior, 18(3), 326-339.

Han, C. H., \& Cho, Y. A. (2016). The relationship between parent career support and career preparation behavior among high school students: Mediating effects of self-encouragement. Korean Journal of Youth Studies, 23(4), 79-107. doi:10.21509/KJYS.2016. 04.23.4.79

Han, S. M., \& Oh, I. S. (2014). The influence of high school students ` perceived parent support and career selfefficacy upon career maturity. Secondary Education Research, 62(1), 261-281

Han, S. M., \& Oh, I. S. (2014). The influence of high school students ` perceived parent support and career selfefficacy upon career maturity. Secondary Education Research, 62(1), 261-281

Jung, Y. H. (2016). Exploration of career education competency of elementary school teachers. Global Creative Leader, 6(2), 49-67.

Kim, S. J. (2005). The influence of career barriers, hope and career decision-making self-efficacy on the career preparation behavior of college students. (Doctoral thesis, Hongik University, Seoul, Korea).

Kim, S. J., \& Lee, J. J. (2013). The effect of career barriers and career decision-making self-efficacy on the career preparation behavior: For middle and high school and specialized high school students. Research on Rehabilitation Psychology, 2011), 119-136
Kim, S. R. (2004). The influence of parent support, career decision-making self-efficacy and dysfunctional career thoughts on adolescents' career development. (Doctoral thesis, Hongik University, Seoul, Korea).

Lee, E. K. (2001). The effect of self-efficacy on career development. (Doctoral thesis, Ewha Woman University, Seoul, Korea).

Lee, H. R., Lee, N. H., \& Lee, Y. O. (2016). The effects of career group counseling program on elementary school students' career consciousness maturity and human relations. Child Education, 15(1), 221-233.

Lee, G. H., \& Lee, H. J. (2000). The effects of career selfefficacy in predicting the level of career attitude maturity of college students. Korean Psychological Association: Counseling and Psychotherapy, 12(1), 127-136.

Lee, J. M., \& Cho, B. R. (2015). Structural relationships among creative personality, university supporting, career maturity, career preparation behavior of university students. Creativity Education Research, 15(4), 41-59

Ministry of Education (2015). Goals of school career education and achievement criteria (commentary). Korea Institute of Vocational Training.

Pečiulytè, E., Ustinavičiūtè, L., \& Norvilè, N. (2014). The relationship between parental involvement and students' career decision self-efficacy. Social Work Research Journal, 13(1), 110-122. doi:10.13165/SD-1413-1-10

Seo, K. H. (2016). The effects of career decision-making self-efficacy and career maturity on career preparation behavior of culinary and foodservice management major students. Culinary Science \& Hospitality Research, 22(3), 121-138. doi:10.20878/ cshr.2016.22.3.011

Taylor, K. M., \& Betz, N. E. (1983). Application of selfefficacy theory to the understanding and treatment of career indecision. Journal of Vocational Behavior, 22(1), 63-81.

Tuner, S. S., Annette, A. B., Lapan, R. T., Udipi, S., \& Ergun, D. (2003). The Career-related parent support scale. Measurement and Evaluation in Counseling and Development, 36(2), 83-94.

Walker, Q. D. (2010). An investigation of the relationship between career maturity, career decision self-efficacy, and self-advocacy of college students with and without disabilities (Doctoral dissertation, University of lowa, lowa City, lowa). Retrieved from: http://ir.uiowa.edu/cgi/ viewcontent. cgi?article=1802 \&context=etd 